\title{
The Effects of Sodium Ricinoleate on Small Intestinal
}

\section{Function and Structure}

\author{
William S. Cline, Vilja Lorenzsonn, Linda Benz, Paul Bass, and \\ WARD A. Olsen \\ From the Gastroenterology Research Laboratory, Madison Veterans Adminis- \\ tration Hospital and the Department of Medicine, University of Wisconsin, \\ Madison, Wisconsin 53706
}

\begin{abstract}
A в S T R A C T The mechanism of hydroxy fatty acidinduced secretion was investigated in perfused hamster small intestine in vivo. Sodium ricinoleate at an $8-\mathrm{mM}$ concentration resulted in not only secretion of water and sodium, but an increase in intestinal clearance of inulin and a 16,000 mol wt dextran as well. A concentration of ricinoleate $(2 \mathrm{mM})$ which did not affect water transport, however, did not alter intestinal permeability. Ricinoleate-induced intestinal secretion was also accompanied by increased mucosal cell exfoliation as measured by the appearance of DNA in the perfusate and by apparent injury to epithelial cell membranes as judged by measurement of sucrase activity and phospholipid in cell-free aliquots of luminal fluid. Light and electron microscopic studies demonstrated substantial mucosal architectural changes with $8 \mathrm{mM}$ ricinoleate with villus shortening and injury to epithelial cells at the villus tips.
\end{abstract}

In contrast, cholera enterotoxin caused marked secretion of sodium and water, presumably by a cyclic AMP mechanism, but did not alter inulin clearance or enhance DNA or sucrase appearance in the lumen.

These studies suggest that at least a component of ricinoleate-induced intestinal secretion is related to structural alterations of the mucosa.

\section{INTRODUCTION}

The reasons for fecal fluid and electrolyte loss in fat malabsorption are not clear, but the finding of increased amounts of hydroxy fatty acids in the stools from such patients (1-5) suggested that these compounds might be responsible (4-6). This possibility was especially attractive because of the well-known cathartic properties of ricinoleic acid, the $\mathrm{C}-18$ hydroxy fatty acid known to be the active component of castor oil (7). It has sub-

Received for publication 6 August 1975 and in revised form 19 March 1976. sequently become clear that not just long chain hydroxy fatty acids, but a variety of nonhydroxy fatty acids as well, induce water and electrolyte secretion by small bowel and colon in both experimental animal and man (8-11). The mechanism of this secretory effect has not been established, however, although a recent report has suggested that cyclic AMP may be the mediator (12) as it is in cholera $(13,14)$. Since sodium soaps of these fatty acids are amphiphiles $(15,16)$, we became interested in the possibility that their secretory effects might be related to their detergent properties rather than to a specific effect on intracellular metabolism. The purpose of this study was to examine the effects of ricinoleic acid on small intestinal mucosa in vivo and to compare some of these effects to those of purified cholera enterotoxin.

\section{METHODS}

Studies of water and sodium absorption. Male Syrian Golden hamsters (Sprague-Dawley, Madison, Wisc.), weighing $80-130 \mathrm{~g}$, were studied with an in vivo perfusion technique. Nonfasting animals were anesthetized with intraperitoneal pentobarbital sodium, $50 \mathrm{mg} / \mathrm{kg}$, the abdomen opened in the midline, and the small bowel cannulated with polyethylene tubing at the ligament of Treitz and at the ileocecal junction. The small bowel was rinsed with $5 \mathrm{ml}$ of warm saline and then perfused with either a control or test solution at $0.75-0.80 \mathrm{ml} / \mathrm{min}$ by a peristaltic perfusion pump (Multi-Speed transmission pump model 1201, Harvard Apparatus Co., Inc., Millis, Mass.). Body temperature was maintained at $37^{\circ} \mathrm{C}$ with a heating blanket and an overhead lamp. (Model 73A, Tele-thermometer, Yellow Springs Instrument Co., Yellow Springs, Ohio). Perfusion solutions were maintained at $38^{\circ} \mathrm{C}$ in a water bath. The control solution contained $2 \mu \mathrm{Ci}$ of $\left[{ }^{14} \mathrm{C}\right]$ polyethylene glycol (PEG) ${ }^{1}$ (sp act $5.5 \mu \mathrm{Ci} / \mathrm{mg}$, New England Nuclear, Boston, Mass.) and $0.5 \mathrm{~g}$ carrier PEG (Carbowax 4,000, Union Carbide Corp., New York) per $100 \mathrm{ml}$ in $154 \mathrm{mM}$ sodium chloride;

${ }^{1}$ Abbreviation used in this paper: PEG, polyethylene glycol. 
test solutions were similar but contained sodium ricinoleate (Nu-Chek-Prep. Incorp., Elysian, Minn.) at 2- and 8-mM concentrations. The $\mathrm{pH}$ of the solution was adjusted to 7.87.9 , and the osmolality varied between 290 and $300 \mathrm{mosmol}$. Preliminary experiments demonstrated the development of a steady state of water transport within the first $20 \mathrm{~min}$ of perfusion; consequently the first 20 -min collection from the distal cannula was discarded and two subsequent 20 -min collections were obtained. The experiment was then terminated, the animal sacrificed, and the perfused segment of small bowel removed and dried to constant weight at $100^{\circ} \mathrm{C}$. Collections from the distal cannula were centrifuged at $1,000 \mathrm{~g}$ for $10 \mathrm{~min}$ to remove debris, and aliquots of supernates and infusion fluid were then assayed for ${ }^{14} \mathrm{C}$ and sodium concentrations. For ${ }^{14} \mathrm{C}$ counting, 200- $\mu \mathrm{l}$ aliquots were mixed with $15 \mathrm{ml}$ of toluene, alcohol, and Liquifluor (New England Nuclear) $(1000: 375: 42)$ and counted in a liquid scintillation spectrometer (Isocap/300, Searle Analytic Inc., Des Plaines, Ill.) with an efficiency for ${ }^{14} \mathrm{C}$ of $91 \%$. Sodium concentrations were measured with a flame photometer (Model 343, Instrumentation Laboratory, Inc., Lexington, Mass.).

Net water and sodium fluxes were calculated for each of the two 20-min collection periods, expressed per gram of dry tissue weight, and the mean value used. The following formulas were used for calculation of net water and sodium flux: water flux = perfusion rate $(1-[P E G] i$ / [PEG]o) and sodium flux = perfusion rate $\left(\mathrm{Na}_{1}-\mathrm{Na}_{0}\right.$ $[\mathrm{PEG}] \mathrm{i} /[\mathrm{PEG}] \mathrm{o})$, where $[\mathrm{PEG}] \mathrm{i}$ and $[\mathrm{PEG}] \mathrm{o}={ }^{14} \mathrm{C} \mathrm{con}-$ centration in the perfusion solution and collection sample and $\mathrm{Na}_{1}$ and $\mathrm{Na}_{0}=$ sodium concentration in perfusion solution and collected sample. Positive values indicate absorption and negative values indicate secretion.

To exclude the possibility that ricinoleate resulted in sufficient absorption of PEG to cause a significant error in calculation of net water flux, total ${ }^{14} \mathrm{C}$ recovered was measured in control perfusions and in perfusions with $8 \mathrm{mM}$ ricinoleate. $110.5 \pm 3.8$ (SEM)\% was recovered in control perfusions and $108.1 \pm 3.3 \%$ with ricinoleate; thus significant absorption of PEG did not occur during our studies.

Assessment of intestinal permeability. Permeability was determined by measurements of intestinal clearance of intravenously administered inulin, a $16,000 \mathrm{~mol}$ wt dextran, and albumin. $25 \mu \mathrm{Ci}$ of $\left[{ }^{14} \mathrm{C}\right]$ inulin ( $\mathrm{Mol}$ wt 6,000 , sp act $1.9 \mu \mathrm{Ci} / \mathrm{mg}$, New England Nuclear), $\left[{ }^{14} \mathrm{C}\right]$ dextran (Mol wt 16,000 , sp act $2.2 \mu \mathrm{Ci} / \mathrm{mg}$, New England Nuclear), or $\left[{ }^{51} \mathrm{Cr}\right.$ ] human serum albumin (Mol wt $60,000,7.8 \mu \mathrm{Ci} / \mathrm{mg}, \mathrm{E}$. R. Squibb \& Sons, Princeton, N. J.) were injected into the inferior vena cava of hamsters and both renal pedicles ligated. The small intestine was then perfused with control or test solution as described above with omission of $\left[{ }^{14} \mathrm{C}\right]-$ PEG. After a 20-min perfusion period to achieve steady. state conditions, four 10 -min collections were obtained. Pre. liminary experiments demonstrated constant plasma concentrations of isotope from 20 to $60 \mathrm{~min}$ after injection so that a single blood sample $60 \mathrm{~min}$ after injection was obtained from the jugular vein in a heparinized capillary tube. Plasma was separated from cells by centrifuging for 10 min with a micro hematocrit centrifuge (Clay-Adams, Inc., Parsippany, N. J.). 20- $\mu 1$ aliquots of plasma and $200-\mu 1$ aliquots of collected samples were mixed with $150 \mu 1$ Soluene TM 100 (Packard Instrument Co., Inc., Downers Grove, I11.) and counted for ${ }^{14} \mathrm{C}$ as described above. For ${ }^{51} \mathrm{Cr}$ counting, aliquots were counted with a gamma counter (Model 5520 Auto Gamma scintillation spectrometer, Packard Instrument Co., Inc.). Clearance was calculated as follows: Clearance $=(V)\left(M_{0}\right) / M_{P}$, where $V=$ volume of collection, $\mathrm{M}_{0}=$ isotope concentration in collected sample, and $\mathrm{M}_{\mathbf{P}}=$ isotope concentration in plasma. Clearances are expressed as milliliters per minute per gram of dry tissue weight. A clearance was calculated for each 10-min collection and then the mean of the four clearances used.

Biochemical assessment of mucosal damage. The rate of appearance of DNA in the intestinal lumen during perfusion was used as an index of epithelial cell exfoliation. Perfusions were carried out as described above; a 20 -min equilibration period was followed by a $40-\mathrm{min}$ collection period with samples collected in $0.5 \mathrm{ml}$ of $0.2 \mathrm{M}$ EDTA over ice and analyzed for DNA (17). Results are expressed as micrograms of atom DNA phosphorus. The rate of DNA appearance in the lumen was calculated.

In separate experiments, collected samples were centrifuged at $1,000 \mathrm{~g}$ for $10 \mathrm{~min}$ at $4^{\circ} \mathrm{C}$ to remove exfoliated cells and the supernates assayed for sucrase or phospholipid. Sucrase activity was measured by the method of Dahlqvist (18). For phospholipid determination, supernates were brought to $\mathrm{pH} 6.8$, extracted twice with chloroform/ methanol, $2: 1$, the solvent layer evaporated to dryness in a rotary evaporator at $37^{\circ} \mathrm{C}$, and phosphorus determined (19).

Morphological studies. In an attempt to determine a structural basis for the increased mucosal permeability found with ricinoleate, we administered the electron opaque tracer lanthanum. In preliminary experiments the following technique was used. After $40 \mathrm{~min}$ of perfusion with either control or test solution containing $8 \mathrm{mM}$ ricinoleate, $1 \mathrm{ml}$ of $3 \%$ lanthanum nitrate (Electron Microscopy Sciences, Fort Washington, $\mathrm{Pa}$.), $4 \%$ sucrose in $0.05 \mathrm{M}$ Tris $\mathrm{HCl}$ buffer, $\mathrm{pH} 7.2$ (20), was injected into the inferior vena cava. 50-60 s later the perfusion solution was replaced with $2.5 \%$ redistilled glutaraldehyde (Polysciences, Inc., Warrington, $\mathrm{Pa}$.) in $0.1 \mathrm{M}$ sodium cacodylate buffer, containing $1 \mathrm{mM}$ calcium chloride, $\mathrm{pH} 7.42,515$ mosmol. After perfusion for approximately $1 \mathrm{~min}$, a ring of jejunum $5-10 \mathrm{~cm}$ distal to the ligament of Treitz was removed, opened, and trimmed in the same fixative into approximately $1-\mathrm{mm}$ wide blocks and fixed for $1 \mathrm{~h}$. The tissue was rinsed and postfixed in $1 \%$ osmium tetroxide, $0.1 \mathrm{M}$ sym-collidine- $\mathrm{HCl}$ buffer, $\mathrm{pH} 7.42$, for $1 \mathrm{~h}$, and stained en bloc in $0.5 \%$ uranyl acetate containing $4 \%$ sucrose.

When it became apparent that ricinoleate resulted in the development of lanthanum permeability through the zone of exfoliation at the villus tips, we added lanthanum to the fixative to increase tracer concentration in this area, thereby providing a better demonstration of the altered permeability. After injection of lanthanum into the inferior vena cava as

TABLE I

Effects of Na Ricinoleate on Clearance of Inulin, Dextran, and Albumin*

\begin{tabular}{lccc}
\hline & $\begin{array}{c}\text { Inulin } \\
\text { clearance } \ddagger\end{array}$ & $\begin{array}{c}\text { Dextran } \\
\text { clearance }\end{array}$ & $\begin{array}{c}\text { Albumin } \\
\text { clearance } \neq\end{array}$ \\
\hline Control & $29 \pm 5(10)$ & $33 \pm 7(4)$ & $30 \pm 11(4)$ \\
$2 \mathrm{mM} \mathrm{Na}$ ricinoleate & $50 \pm 15(8)$ & Not studied & Not studied \\
$8 \mathrm{mM} \mathrm{Na}$ ricinoleate & $359 \pm 86(5) \S$ & $115 \pm 14(4) \|$ & $26 \pm 13(4)$ \\
\hline
\end{tabular}

* Mean \pm SEM are shown and numbers of animals are given in parentheses. $\mp$ Clearance expressed as milliliters per minute per gram dry weight $\times 10^{4}$ 8 Significant change from control, $P<0.001$.

\| Significant change from control, $P<0.01$. 
TABLE II

Effect of Na Ricinoleate on Luminal Appearance of DNA, Sucrase, and Phospholipid*

\begin{tabular}{llll}
\hline & \multicolumn{1}{c}{ DNA } & \multicolumn{1}{c}{ Sucrase } & \multicolumn{1}{c}{ Phospholipid\| } \\
\hline Control perfusion & $12.11 \pm 7.45(9)$ & $9.4 \pm 2.2(12)$ & $21.19 \pm 1.94(9)$ \\
$2 \mathrm{mM} \mathrm{Na}$ ricinoleate & $36.71 \pm 15.11(7)$ & $13.4 \pm 4.7(4)$ & $49.58 \pm 21.27(4)$ \\
$8 \mathrm{mM} \mathrm{Na}$ ricinoleate & $37.00 \pm 10.00(5) \Phi$ & $93.7 \pm 9.1(5)^{* *}$ & $52.03 \pm 7.72(13) \ddagger \ddagger$
\end{tabular}

* Mean \pm SEM are shown. Numbers of animals are given in parentheses.

$\ddagger$ Expressed as micrograms of atom DNA P per minute $\times 10^{4}$.

$\S$ Expressed as units per minute $\times 10^{3}$.

|| Expressed as micrograms of $\mathrm{P}$ per minute $\times 10^{2}$.

II Significant change from control, $P<0.05$.

** Significant change from control, $P<0.001$.

$\sharp$ Significant change from control, $P<0.01$.

above, the intestine was perfused with $1 \%$ lanthanum hydroxide (21) in $0.1 \mathrm{M}$ sodium cacodylate buffer, $\mathrm{pH}$ 7.3, 584 mosmol. The tissue was trimmed in this fixative and fixed for $2 \mathrm{~h}$ at room temperature on a tilting rotary shaker adjusted to less than $1 \mathrm{rpm}$. The tissue was rinsed and postfixed overnight in cold $1 \%$ osmium tetroxide, $1 \%$ lanthanum, in $0.1 \mathrm{M}$ sym-collidine- $\mathrm{HCl}$ buffer, $\mathrm{pH} 7.3,300$ mosmol, and stained with $0.5 \%$ uranyl acetate, $4 \%$ sucrose, for $1 \mathrm{~h}$.

All tissues were dehydrated in graded alcohols and propylene oxide and flat-embedded in Epon 812 (Shell Chemical Corp., New York) (22). Sections were cut at right angles to the serosa and stained for light microscopy with $0.5 \%$ toluidine blue $\mathrm{O}$ in $0.1 \mathrm{M}$ phosphate buffer, $\mathrm{pH}$ 7.0. Villi including the zone of exfoliation were selected for electron microscopy and examined with or without light counterstaining with lead citrate with a Philips EM 301 electron microscope (Philips Electronic Instruments, Inc., Mount Vernon, N. Y.). The distal two-thirds of villi were surveyed at magnifications ranging from $\times 600$ to 7,500 ; all tight junctions sectioned at approximately right angles to the membranes were recorded at $\times 60,000$. Conclusions were based upon examination of 300 micrographs.

To quantitate the morphological results, the length of
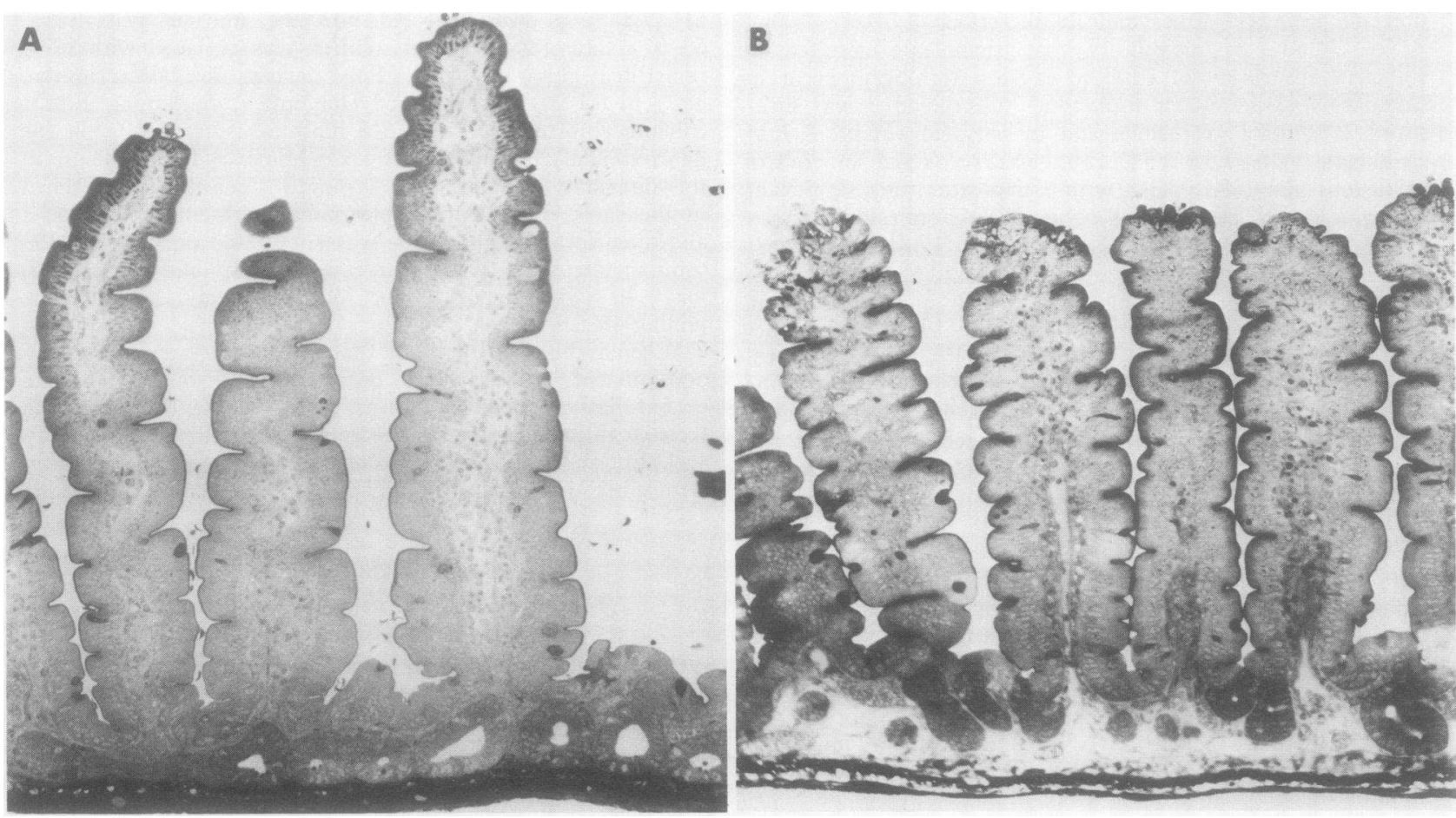

Figure 1 Jejunal mucosa after $40 \mathrm{~min}$ of control perfusion (A) and perfusion with $8 \mathrm{mM}$ ricinoleate (B). After ricinoleate perfusion the villi are shorter and many villus tip cells appear to be exfoliating. (Magnification $\times 130$ ). 


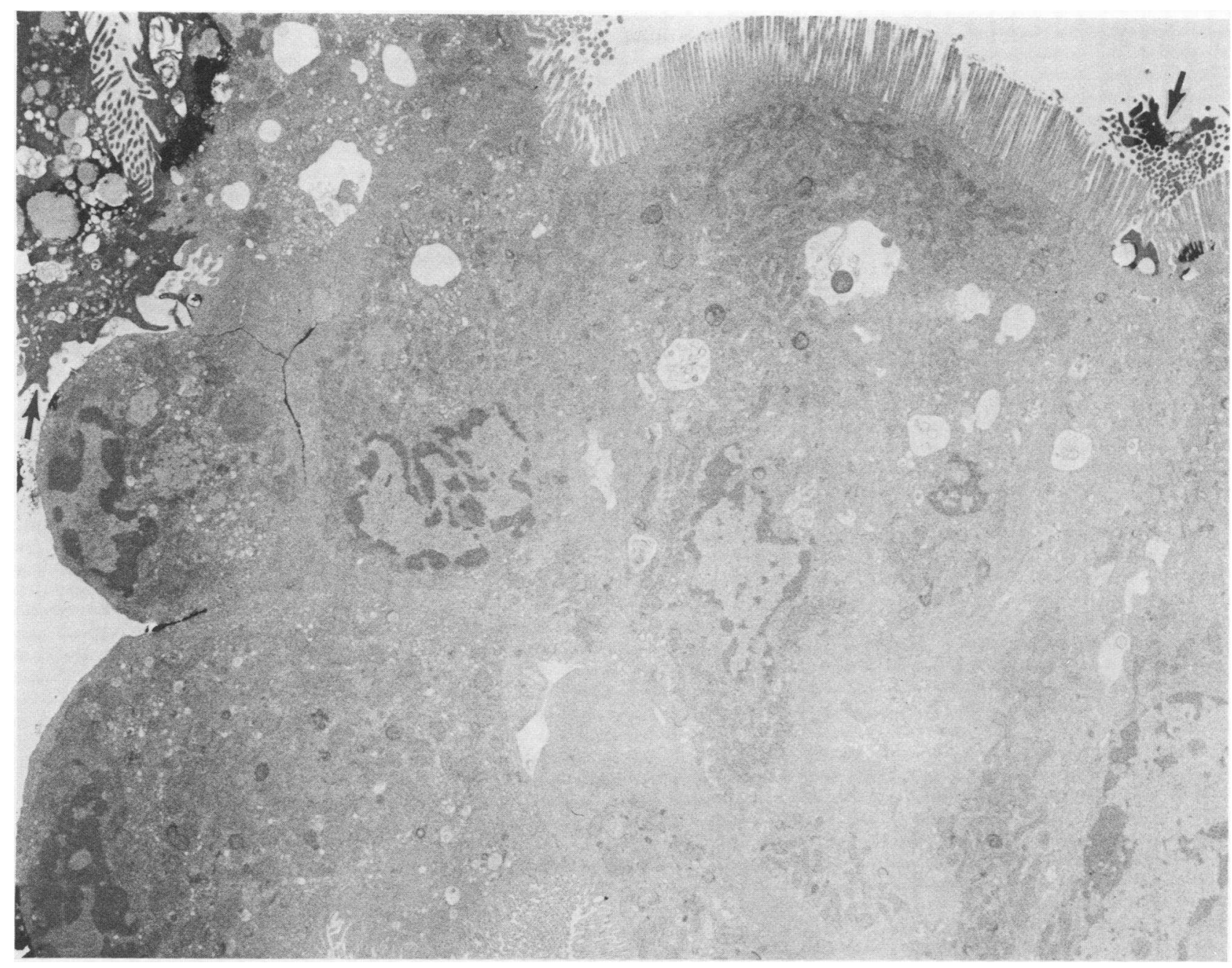

FIGURE 2 The area of exfoliation at the tip of the villus during control perfusion. Only a few cell fragments within the lumen are electron opaque due to lanthanum staining (arrows). (Magnification $\times 4,900$ ).

the five longest villi and the length of the corresponding crypts of each coded specimen were measured at a $\times 120$ magnification with a Zeiss light microscope (Carl Zeiss, Inc., New York) equipped with a 5-mm micrometer disk with 100 divisions. In addition, two blocks from each animal where lanthanum was present in the fixation (three animals perfused with control solution and four perfused with $8 \mathrm{mM}$ ricinoleate) were sectioned for electron microscopy. Each section contained one or more villi. Electron opaque absorptive cells (stained with lanthanum) were counted in enlargements of negatives taken at a magnification of $\times 600$ (Fig. 4) with cell type confirmed at a magnification of $\times 5,500$ to exclude exhausted goblet cells.

Experiments with cholera toxin. After initial rinsing of the small bowel, 2-3 ml of either control solution or an identical solution containing $4 \mu \mathrm{g} / \mathrm{ml}$ of purified cholera enterotoxin $^{2}$ were instilled into the small intestine and left

2 Prepared by Schwarz/Mann Div., Becton, Dickinson \& Co., Orangeburg, N. Y., according to the method of Finkelstein and LoSpalluto (23). in place for $60 \mathrm{~min}$. Thereafter, perfusion was begun and the techniques described above used to assess net water and sodium flux, intestinal permeability, DNA, and sucrase activity.

Expression of results. Control and experimental animals were studied simultaneously because of normal seasonal

TABLE III

Morphological Measurements after Sodium Ricinoleate*

\begin{tabular}{lcc}
\hline & $\begin{array}{c}\text { Length of } \\
\text { villus }\end{array}$ & $\begin{array}{c}\text { Length of } \\
\text { crypt! }\end{array}$ \\
\hline Control & $619.6 \pm 43.1(6)$ & $85.6 \pm 8.1(6)$ \\
$8 \mathrm{mM} \mathrm{Na}$ ricinoleate & $444.6 \pm 19.3(8)$ & $95 \pm 3.5(8)$ \\
Significance of difference & $P<0.01$ & $\mathrm{NS}$
\end{tabular}

* Mean \pm SEM are given. Numbers of animals are given in parentheses.

$\ddagger$ Values given in microns. 


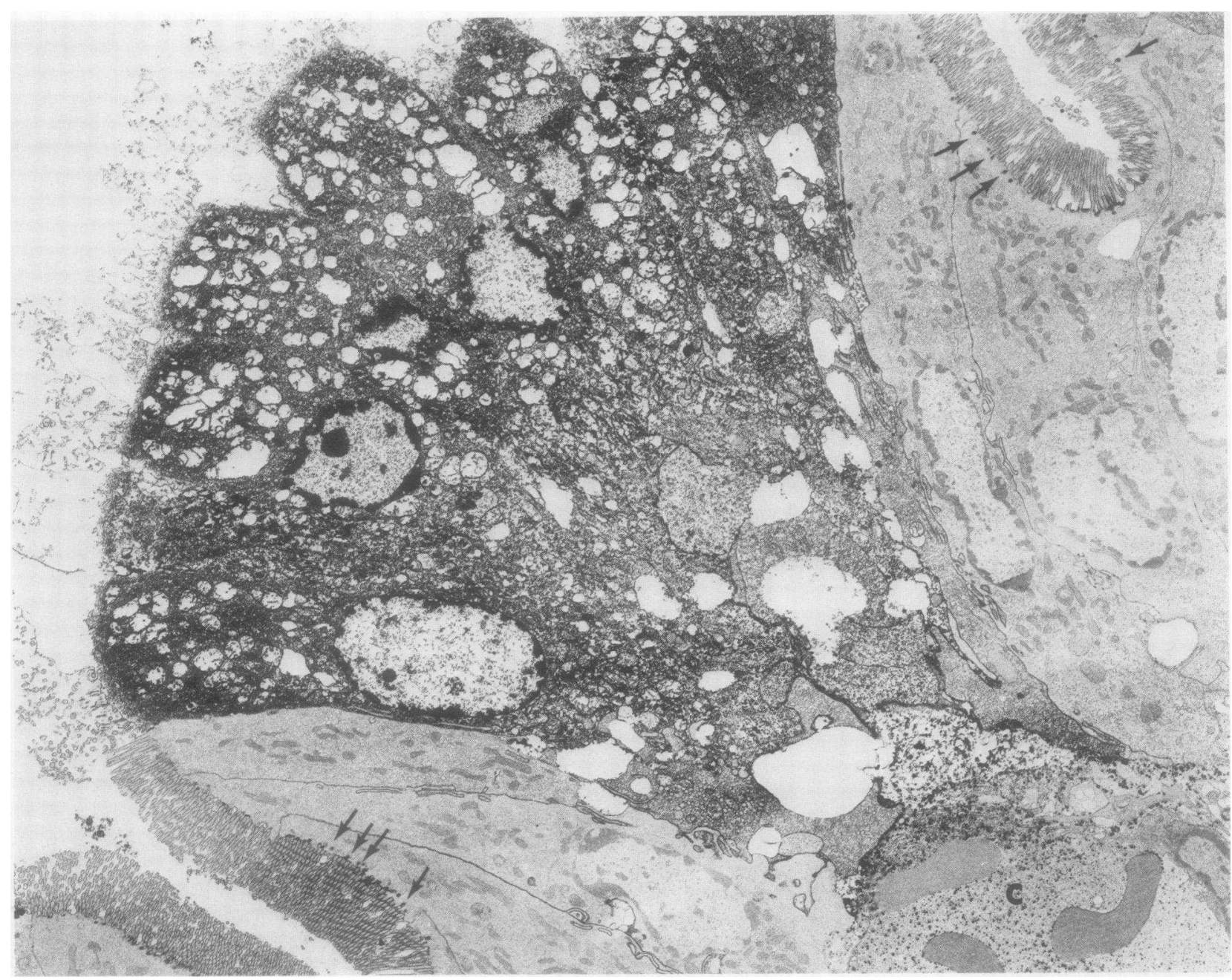

FIGURE 3 The tip of the villus after perfusion with $8 \mathrm{mM}$ ricinoleate. The cytoplasm of several absorptive cells is vacuolated and electron opaque due to lanthanum staining. The brush borders have disintegrated. Lanthanum is also present in the capillary (C), the lamina propria, and the intercellular spaces. Adjacent absorptive cells forming epithelial infoldings (sulci) have a dilated smooth endoplasmic reticulum and lanthanum-stained caveolae (arrows) between microvilli. (Magnification $\times 4,900$ ).

variation in water and sodium absorption (24). In our studies no seasonal variation was found, so results were pooled.

\section{RESULTS}

Net water and sodium flux. Sodium ricinoleate at the 2-mM concentration had no effect on fluid transport. Mean absorption in 34 control perfusions was $0.0252 \pm$ $0.0169(\mathrm{SEM}) \mathrm{ml} / \mathrm{min}$ per $\mathrm{g}$ dry weight and $0.0262 \pm$ 0.0299 in 11 perfusions with $2 \mathrm{mM}$ ricinoleate. Sodium transport was also not affected with $-3.788 \pm 4.350 \mu \mathrm{eq} /$ min per $g$ dry weight in controls and $-5.738 \pm 7.383$ with $2 \mathrm{mM}$ ricinoleate. Frank secretion into the lumen, however, occurred with the $8-\mathrm{mM}$ concentration $(-0.1179 \pm 0.0398 \mathrm{ml} / \mathrm{min}$ per $\mathrm{g}$ dry weight in 13 perfusions, $P<0.01$ compared to controls). The $8-\mathrm{mM}$ concentration also resulted in sodium secretion $(-66$.$110 \pm 20.560 \mu \mathrm{eq} / \mathrm{min}$ per $\mathrm{g}$ dry weight, $P<0.01 \mathrm{com}$ pared to controls).

Intestinal permeability. Plasma concentrations of isotope did not differ between control and ricinoleate experiments; for example, with inulin, mean concentration was $47,116 \pm 5,448$ (SEM) $\mathrm{cpm} / 20 \mu \mathrm{l}$ with controls and $48,164 \pm 1,930$ with $8 \mathrm{mM}$ ricinoleate. Intestinal clearance of inulin was not affected by perfusion of 2 $\mathrm{mM}$ ricinoleate (Table I) so that clearance of dextran and albumin was not studied at that concentration. However, $8 \mathrm{mM}$ ricinoleate resulted in a 12 -fold increase in inulin clearance and a less striking, but significant enhancement of dextran clearance. Albumin clearance was not altered. 
Biochemical assessment of mucosal damage. Ricinoleate at the 8-mM concentration resulted in a threefold increase in the rate of DNA appearance in perfusates consistent with increased cell exfoliation (Table II). Although mean DNA appearance during perfusion at the 2-mM concentration was similarly increased, individual variation was such that this was not statistically significant.

To look for possible effects of sodium ricinoleate on membranes of absorptive cells, we measured sucrase activity and phospholipid in cell-free supernates of perfusate. There was a marked increase in sucrase activity at the 8-mM concentration, but no effect was found with a 2-mM concentration. Phospholipid appearance was also significantly increased with $8 \mathrm{mM}$ ricinoleate with a variable response at the $2-\mathrm{mM}$ concentration which was not statistically significant.

Morphological studies. Fig. 1 illustrates representative light micrographs after a control perfusion and a perfusion containing $8 \mathrm{mM}$ ricinoleate. Villi were shortened after ricinoleate and the distal epithelial cells appeared metachromatic and vacuolated. Table III illustrates that ricinoleate decreased villus height but did not affect crypt length.

Lanthanum, an electron-opaque tracer, has been used previously to study extracellular material (25) and to assess permeability of tight junctions (20). We used lanthanum in our electron microscopic studies in an attempt to define a structural basis for the increased mucosal permeability found with $8 \mathrm{mM}$ ricinoleate. In preliminary experiments the tracer was given only by intravenous injection. Lanthanum was found in the area of exfoliation after perfusion with $8 \mathrm{mM}$ ricinoleate, but not after control perfusion. To facilitate quantitation of this altered permeability, we included lanthanum in the fixative to increase the staining. The following description refers to these studies.

In control perfusions, lanthanum was alway excluded from the area of membrane fusion of tight junctions (zonula occludens) and was also excluded from intact absorptive cells, although it did penetrate secreting goblet cells and some exfoliating cells at the villus tips with the development of electron opacity as shown in Figs. 2, 4A, and 5A. In the proximal villus, the brush borders of absorptive cells were negatively outlined by an extracellular layer of lanthanum, but distally, staining was patchy and on some microvilli consisted of only a fine layer.

After perfusion with $8 \mathrm{mM}$ ricinoleate, as shown in Figs. 3, 4B, and 5B, villus tips were capped with vacuolated epithelial cells with disintegrating brush borders. These cells were electron opaque because of lanthanum penetration, and continuity of the tracer between the capillaries and the intestinal lumen was apparent in these

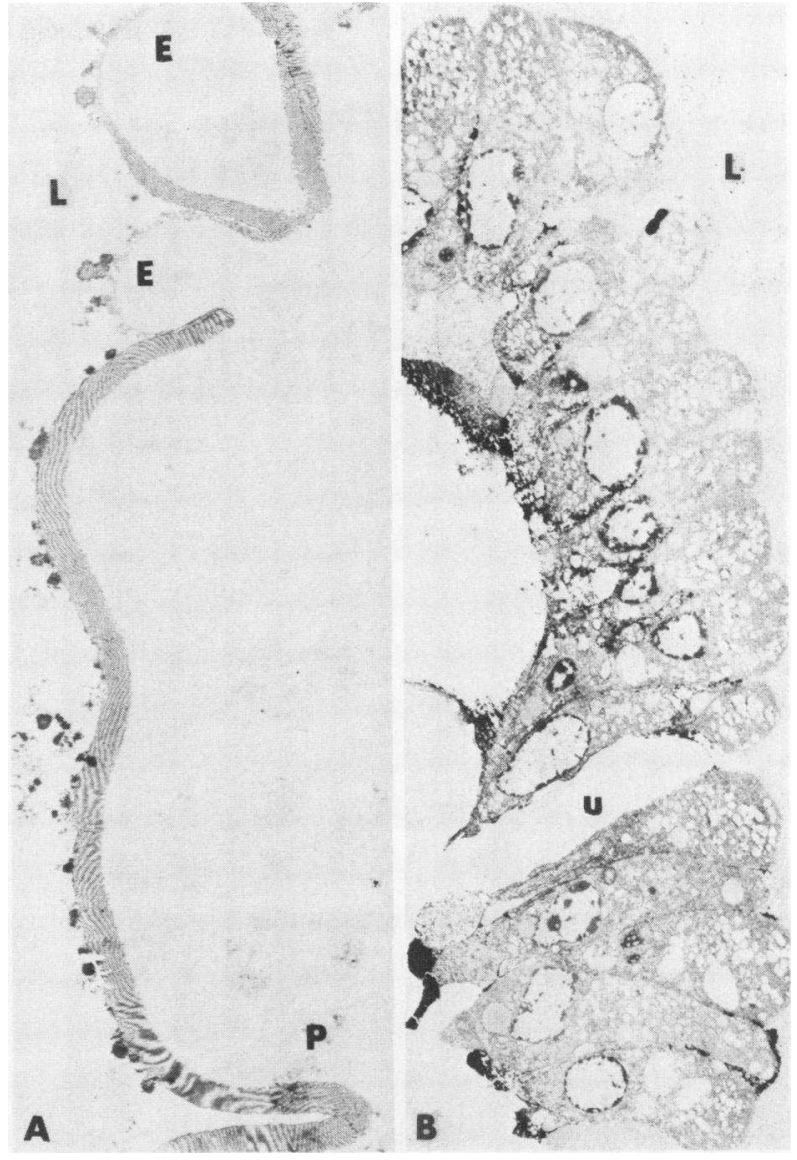

Figure 4 Examples of micrographs of the distal villus used for quantitation of numbers of lanthanum-stained cells. Lumen is indicated by ' $L$ '. (A) Control. Lanthanum staining outlines the brush border. Exfoliating cells (E) are minimally stained. ' $P$ ' marks particles that have been displaced by the edge of the knife. (Magnification $\times 1,400$ ) (B) After $8 \mathrm{mM} \mathrm{Na}$ ricinoleate. The distal absorptive cells are electron opaque. One cell remained unstained (u). (Magnification $\times 1,200)$.

areas. Adjacent absorptive cells stained variably and contained dilated smooth endoplasmic reticulum (Figs. 3, 4B, and 5B). Lanthanum was excluded from tight junctions in all sections examined as shown in Fig. $5 \mathrm{C}$. Although the extracellular layer of lanthanum was unchanged in the proximal villus, distally the pattern was altered. Electron lucent spheroidal dilatations of the space between the bases of microvilli were outlined by lanthanum staining (Figs. 5B and 5D). These areas were stained, however, within relatively protected areas of epithelial infolding (Fig. 3).

Electron opaque cells were counted as described under Methods. We found $1.67 \pm 0.42$ (SEM) cells per villus with control perfusions, and $13.75 \pm 1.45$ with ricinoleate $(P<0.001)$. 

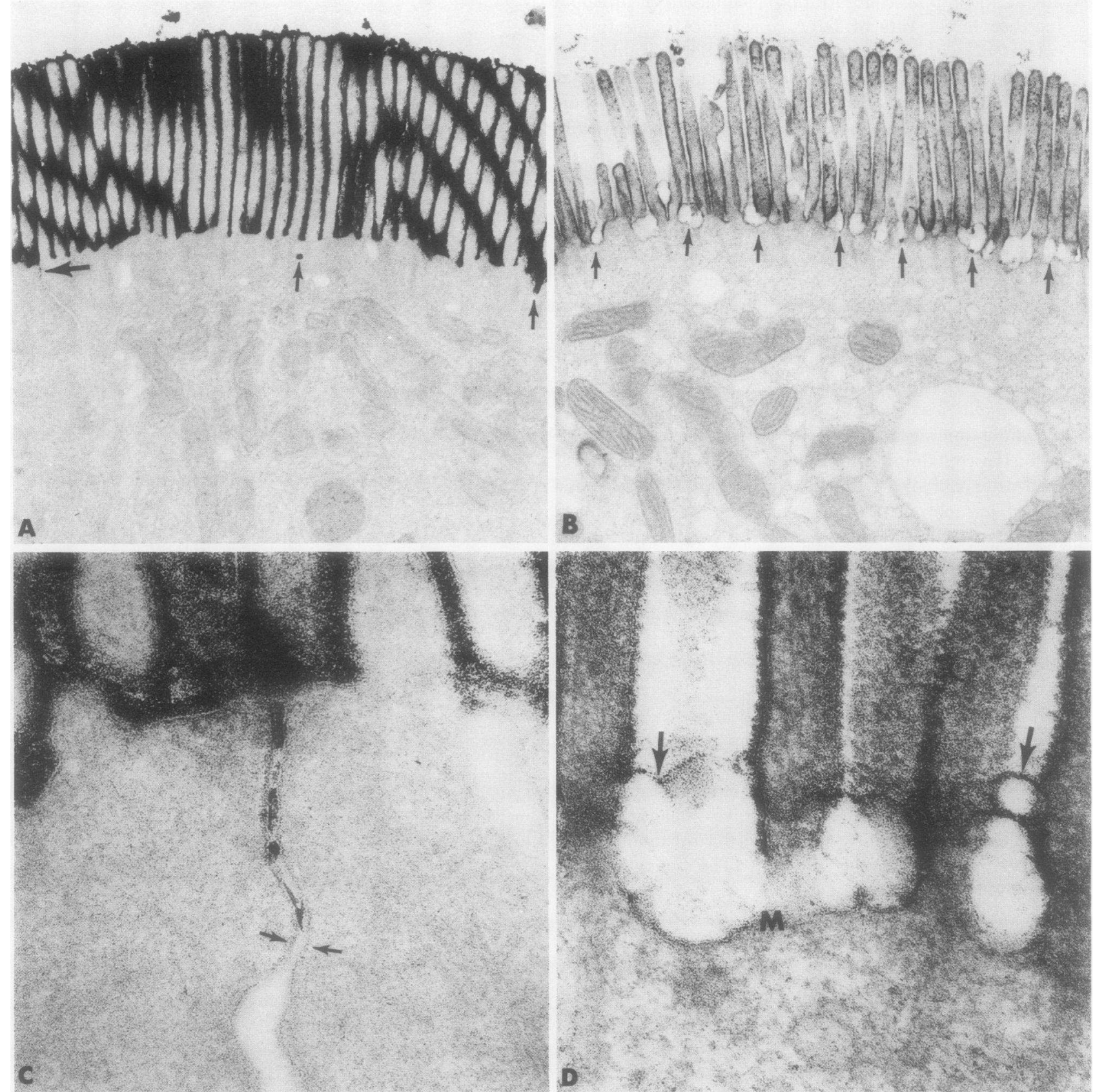

Figure 5 Apical area of absorptive cells of the distal villus. (A) Control. Microvilli are closely spaced with lanthanum apparent in infrequent caveolae (small arrow) and in the groove associated with the tight junction (large arrow) (Magnification $\times 16,200$ ). (B) After ricinoleate, the spaces at the base of microvilli, presumably dilated caveolae, are unstained (arrows). Dilated smooth endoplasmic reticulum is also apparent (Magnification $\times 16,200$ ). (C) Tight junction of distal epithelial cells after ricinoleate. Lanthanum penetration appears limited by the area of membrane fusion (arrows) (Magnification $\times 108,000$ ). (D) Dilated spaces after ricinoleate as in (B). Lanthanum staining demarcates the cell membrane (M) and lamina at the luminal margin (arrows) which was not visible when lanthanum was omitted from the fixation (Magnification $\times 108,000$ ). 
TABLE IV

Effects of Cholera Enterotoxin on Hamster Small Bowel*

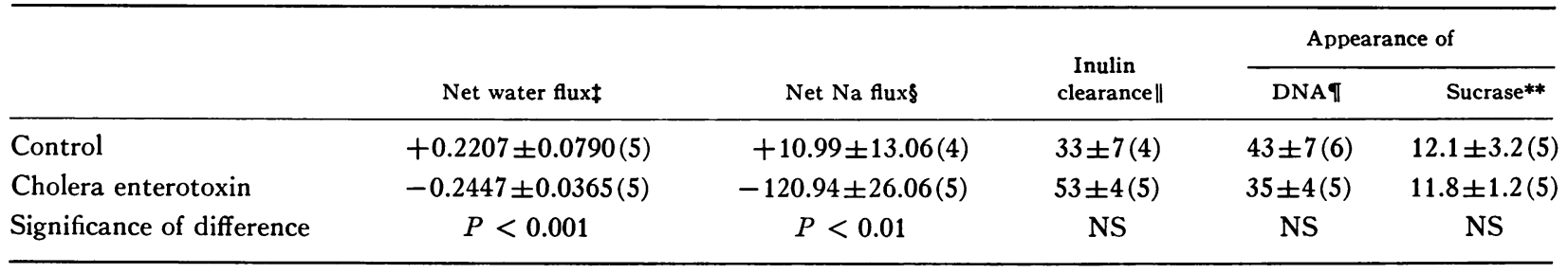

$*$ Mean $\pm \mathrm{SEM}$ are shown. Number of animals are given in parentheses.

$\ddagger$ Expressed as milliliters per minute per gram of dry wt. Positive numbers indicate absorption and negative numbers indicate secretion.

$\S$ Expressed as microequivalents per minute per gram of dry wt. Positive numbers indicate absorption and negative numbers indicate secretion.

$\|$ Expressed as milliliters per minute per gram of dry wt $\times 10^{4}$.

I Expressed as micrograms of atoms DNA P per minute $\times 10^{4}$.

** Expressed as units per minute $\times 10^{3}$.

Studies with cholera enterotoxin. Although cholera enterotoxin elicited a marked secretory response (about twice that obtained with $8 \mathrm{mM}$ ricinoleate) it did not change the rate of appearance of DNA or sucrase in the lumen and produced an insignificant change in inulin clearance (Table IV). It should be noted that both absorption rates and DNA appearance during control perfusions in these experiments were greater than with the control perfusions in the ricinoleate experiments, probably because of the different experimental design with an initial 1-h incubation period in the enterotoxin experiments.

\section{DISCUSSION}

Long chain fatty acids, when present within the lumen of jejunum (10), ileum (11), and colon (9), alter transport of water and electrolytes. Depending on the fatty acid used and its concentration, both inhibition of absorption and frank secretion have been found. For example, Bright-Asare and Binder demonstrated that 2 $\mathrm{mM}$ ricinoleate induced secretion by rat colon while oleic acid at the same concentration resulted in about a $40 \%$ inhibition of fluid absorption (8). The effect is related to fatty acid chain length; hexanoic acid does not inhibit water transport (26), but fatty acids above C7 do with an increasing effect with increasing chain length (11). A hydroxyl group is not critical for the effect (11), nor is a double bond if a hydroxyl group is present (27). The nature of the polar group is also not thought important as the effect persists after conjugation with taurine with conversion of the carboxylate group to a sulfonate (11).

The mechanism of the secretory effect has been unclear. An alteration in bowel motility is not the explanation. Although ricinoleic acid uncouples the basic electric rhythm (slow wave) (28-29) and inhibits circular smooth muscle (30), these changes could not induce secretion. In addition, fatty acids have been shown to alter water movement in in vitro preparations where there is essentially no motor activity $(30,31)$. The possible mechanism that has received the most attention is that fatty acids may increase the concentrations of cyclic AMP in the mucosa with a consequent stimulation of electrolyte and water secretion as in cholera. Indeed, increased levels of cyclic AMP in colonic tissue after incubation with ricinoleic acid have been found (12). There are a number of observations in the literature, however, which are difficult to reconcile with the concept of a pure cyclic AMP mediated response. First, fatty acids have been reported to alter not only water and electrolyte transport, but absorption of a number of other substances as well, including glucose, bile acid, xylose, L-leucine, L-lysine, and folic acid (11). These observations suggest a fairly nonspecific effect. Second, at least in rat colon, ricinoleate has been shown to increase mucosal permeability to inulin (8), whereas in cholera, where secretion is apparently mediated by cyclic AMP, there is no change in permeability (32). These observations suggest the possibility that fatty acids induce intestinal secretion by a less specific mechanism, perhaps by damaging the mucosa. Our studies were designed to evaluate this possibility.

We studied the effects of two concentrations of ricinoleate: a concentration which did not affect fluid absorption $(2 \mathrm{mM})$ and one which resulted in secretion $(8 \mathrm{mM})$. Although we did not measure luminal concentrations of ricinoleate, it is likely that they were appreciably lower than in the original infusion solution because of absorption throughout the small bowel. Differences in species, the portion of bowel perfused, and length of study segment with different mean intraluminal concentrations of ricinoleate probably account for the fact that 
others have found secretion at lower concentrations than those used here (9-12). The important point is the correlation we found between secretory response and evidence of mucosal damage. Ricinoleate at a concentration of $2 \mathrm{mM}$ did not alter water and sodium absorption, affect inulin clearance, or significantly change the rate of DNA appearance in the lumen. An 8-mM concentration, however, elicited not only secretion, but markedly increased intestinal permeability to both inulin and a high molecular weight dextran and increased the rate of appearance of DNA in intestinal fluid.

To examine the possibility of cell membrane damage we assayed for sucrase activity and phospholipid, both of which are components of apical cell membrane of absorptive cells. We found a significant increase in concentrations of both in cell-free supernates after the 8-mM ricinoleate perfusions, but not with the $2-\mathrm{mM}$ perfusions.

Our findings suggest that mucosal damage from ricinoleate is a concentration-dependent phenomenon. At the 2-mM concentration inulin clearance and phospholipid and DNA release were increased, although the changes were not statistically significant. We have also found a minimal increase in lanthanum permeable cells at that concentration. $^{s}$ In addition, recent studies in our laboratory have shown that although a 4-mM concentration causes no change in sucrase release, it results in an intermediate increase in inulin clearance $(153 \pm 25 \mathrm{ml} / \mathrm{min}$ per $g$ dry weight $\times 10^{4}$ ), and increases in both DNA release $\left(42 \pm 4 \mu \mathrm{g}\right.$ atom DNA $\left.\mathrm{P} / \mathrm{min} \times 10^{4}\right)$ and fluid secretion $(-0.1095 \pm 0.0678 \mathrm{ml} / \mathrm{min}$ per $\mathrm{g}$ dry weight) similar to those seen with the 8-mM concentration." Meaningful interpretation of these dose-response relationships, however, is difficult in an in vivo situation where mucosal damage with secretion may occur in one region with fluid reabsorption in another. The observations at the 4-mM concentration, however, further support the concept that mucosal damage with cell membrane injury and exfoliation of cells occurs during ricinoleate-stimulated secretion.

Our morphological studies provided more direct evidence of mucosal damage with ricinoleate. Intestinal villi, studied by light microscopy, were shortened with evidence of cell damage at the villus tips. Cells appeared to be exfoliating from the villus tip, thus accounting for the increased rate of appearance of DNA in the lumen. Electron microscopic studies confirmed the damage to intestinal absorptive cells with disintegration of brush borders probably explaining the increased release of sucrase activity and phospholipid into the lumen.

We carefully examined the tight junctions between absorptive cells, since the finding of increased permeability to inulin and dextran suggested the possibility

\footnotetext{
${ }^{3}$ Cline, W., V. Lorenzsonn, L. Benz, and W. A. Olsen. Unpublished observations.
}

of an extracellular route for fuid movement. The areas of membrane fusion appeared to be impermeable to lanthanum, however, suggesting that the tight junctions were not altered (Fig. 5C) and were probably impermeable to inulin and dextran. We believe that the route for tracer movement was not through tight junctions but across the damaged cells or areas of exfoliating epithelium at the villus tip. Villus tip cells developed permeability to lanthanum after ricinoleate perfusion, and in oriented sections, staining with this tracer appeared continuous from capillaries to the lumen through these cells (Fig. 3). Thus, hydrostatic capillary pressure may be the driving force for fluid secretion with ricinoleate.

The finding of lanthanum exclusion from dilitations of the extracellular space between microvilli (Fig. 5B and $D$ ) is difficult to interpret. It may be the earliest morphological evidence of an effect on the cell membrane with a possible loss of binding sites for lanthanum which is thought to attach to calcium binding sites (33).

Several observations suggest that ricinoleate-induced secretion is the consequence of epithelial cell injury rather than an unrelated phenomenon. (a) We found substantial evidence of mucosal injury at the concentration which produced secretion and not at the $2-\mathrm{mM}$ concentration. (b) Since ricinoleate increased intestinal clearance of the large molecules inulin and dextran, the conclusion that fluid movement occurred through the same channels seems inescapable. (c) Studies in both colon $(8)$ and small intestine ${ }^{3}$ suggest that altered permeability and secretion are at least temporally related; that is, both increased permeability and secretion were found during the first measurements after ricinoleate was introduced and both markedly had changed towards normal by the time the first measurements were made after ricinoleate was discontinued. $(d)$ Since cholera enterotoxin does not result in altered inulin permeability, DNA or sucrase release, or lanthanum permeability, ${ }^{4}$ mucosal injury with ricinoleate cannot be the nonspecific consequence of secretion in general or of cyclic AMP-induced secretion in particular. We cannot exclude the possibility, however, that an additional mechanism, perhaps cyclic AMP mediated, contributed to the secretory response.

We believe that the most likely explanation for the mucosal injury with ricinoleate is related to the detergent properties of the molecule. Fatty acid soaps have well-known detergent properties, and the ability of sodium ricinoleate to lyse membranes of other cells has clearly been demonstrated (34). Since a variety of amphiphilic substances such as other fatty acids, bile salts, and various laxative agents also alter intestinal fluid transport (35), it seems likely that their mecha-

\footnotetext{
"Lorenzsonn, V., and W. A. Olsen. Unpublished observations.
} 
nism of action may be, at least in part, related to mucosal injury. Previous reports of no structural alteration with amphiphile-induced secretion $(8,23)$ have been based solely on light microscopy where the changes would not be readily apparent. Though as yet inconclusive, there is suggestive evidence that other amphiphiles damage the intestinal mucosa at concentrations which alter fluid transport. Thus, oleic acid at a $2-\mathrm{mM}$ concentration has been reported to both decrease colonic fluid absorption and to increase inulin clearance by that organ (8). In addition, although in man hexanoic acid does not alter water transport (26), we have found that an $8-\mathrm{mM}$ concentration in hamsters not only induces secretion but results in enhanced sucrase release and the development of epithelial cell permeability to lanthanum as well." Finally, studies of deoxycholate in our laboratory have demonstrated a close relationship between effects on fluid transport and mucosal injury. ${ }^{3}$ It is thus a reasonable hypothesis that amphiphiles induce intestinal secretion because they solubilize components of and ultimately destroy the brush border membrane of intestinal absorptive cells.

\section{ACKNOWLEDGMENTS}

This study was supported by grant AM 13927 from the National Institutes of Health and by Veterans Administration Research funds.

\section{REFERENCES}

1. James, A. T., J. P. W. Webb, and T. D. Kellock. 1961. The occurrence of unusual fatty acids in faecal lipids from human beings with normal and abnormal fat absorption. Biochem. J. 78: 333-339.

2. Kim, Y. S., and N. Spritz. 1968. Hydroxy acid excretion in steatorrhea of pancreatic and nonpancreatic origin. N. Engl. J. Med. 279: 1424-1426.

3. Kellock, T. D., J. R. Pearson, R. I. Russell, J. A. Walker, and H. S. Wiggins. 1969. The incidence and clinical significance of faecal hydroxy fatty acids. Gut. 10: 1055. (Abstr.)

4. Hoffman, A. F., J. R. Poley, H. S. Mekhjian, and S. F. Phillips. 1970. Hydroxy fatty acid: An apparent cause of diarrhea in patients with ileal resection and steatorrhea. J. Clin. Invest. 49: 44a. (Abstr.)

5. Soong, C. S., J. B. Thompson, J. R. Poley, and D. R. Hess. 1971. The role of hydroxy fatty acids in diarrhea. Gastroenterology. 60: 722. (Abstr.)

6. Hoffman, A. F., and J. R. Poley. 1972. Role of bile acid malabsorption in pathogenesis of diarrhea and steatorrhea in patients with ileal resection. I. Response to cholestyramine or replacement of dietary long chain triglyceride by medium chain triglyceride. Gastroenterology. 62: 918-934.

7. Masri, M. S., L. A. Goldblatt, F. DeEds, and G. O. Kohler. 1962. Relation of cathartic activity to structural modifications of ricinoleic acid of castor oil. $J$. Pharm. Sci. 51 : 999-1002.

8. Bright-Asare, P., and H. J. Binder. 1973. Stimulation of colonic secretion of water and electrolytes by hydroxy fatty acids. Gastroenterology. 64: 81-88.

9. Ammon, H. V., and S. F. Phillips. 1973. Inhibition of colonic water and electrolyte absorption by fatty acids in man. Gastroenterology. 65: 744-749.

10. Ammon, H. V., P. J. Thomas, and S. F. Phillips. 1974. Effects of oleic and ricinoleic acids in net jejunal water and electrolyte movement. Perfusion studies in man. $J$. Clin. Invest. 53: 374-379.

11. Ammon, H. V., and S. F. Phillips. 1974. Inhibition of ileal water absorption by intraluminal fatty acids. Influence of chain length, hydroxylation, and conjugation of fatty acids. J. Clin. Invest. 53 : 205-210.

12. Binder, H. J. 1974. Cyclic adenosine monophosphate controls bile salt and hydroxy fatty acid-induced colonic electrolyte secretion. J. Clin. Invest. 53: 7a-8a. (Abstr.)

13. Field, M. 1971. Intestinal secretion: effect of cyclic AMP and its role in cholera. N. Engl. J. Med. 284: 1137-1144.

14. Powell, D. W., R. W. Farris, and S. T. Carbonetto. 1974. Theophylline, cyclic AMP, choleragen, and electrolyte transport by rabbit ileum. Am. J. Physiol. 227: 1428-1435.

15. Mukerjee, P., and W. J. Mysels. 1971. Critical micelle concentration of aqueous surfactant system. U. S. Department of Commerce. U. S. Government Printing Office, Washington, D. C. 1st edition. 222 pp.

16. Helenius, A., and K. Simons. 1975. Solubilization of membranes by detergents. Biochim. Biophys. Acta. 415: 29-79.

17. Croft, D. N., and M. Lubran. 1965. The estimation of deoxyribonucleic acid in the presence of sialic acid: application to analysis of human gastric washings. Biochem. J. 95 : 612-620.

18. Dahlqvist, A. 1968. Assay of intestinal disaccharidases. Anal. Biochem. 22: 99-107.

19. Bartlett, G. R. 1959. Phosphorous assay in column chromatography. J. Biol. Chem. 234: 466-468.

20. Friend, D. S., and N. B. Gilula. 1972. Variations in tight and gap junctions in mammalian tissues. J. Cell Biol. 53: 758-776.

21. Neaves, W. B. 1973. Permeability of Sertoli cell tight junctions to lanthanum after ligation of ductus deferens and ductuli efferentes. J. Cell Biol. 59: 559-572.

22. Luft, J. H. 1961. Improvements in epoxy resin embedding methods. J. Biophys. Biochem. Cytol. 9: 409-414.

23. Finkelstein, R. A., and J. J. LoSpalluto. 1970. Production of highly purified choleragen and choleraginoid. $J$. Infect. Dis. 121 (Suppl.): S63-S72.

24. Teem, M. V., and S. F. Phillips. 1972. Perfusion of the hamster jejunum with conjugated and unconjugated bile acids; inhibition of water absorption and effects on morphology. Gastroenterology. 62: 261-267.

25. Overton, J. 1968. Localized lanthanum staining of the intestinal brush border. J. Cell Biol. 38: 447-452.

26. Zurier, R. B., J. F. Patterson, and R. Levitan. 1968. Relationship between net water absorption and hexanoic acid absorption from the intact human jejunum. $\mathrm{Am}$. J. Dig. Dis. 13: 109-112.

27. Gaginella, T. S., J. J. Stewart, W. A. Olsen, and P. Bass. 1975. Actions of ricinoleic acid and structurally related fatty acids on the gastrointestinal tract. II. Effects on water and electrolyte absorption in vitro. J. Pharmacol. Exp. Ther. 195: 355-361.

28. Christensen, J., N. W. Weisbrodt, and R. L. Hauser. 1972. Electrical slow wave of the proximal colon of the cat in diarrhea. Gastroenterology. 62: 1167-1173.

29. Christensen, J., and B. W. Freeman. 1972. Circular muscle electromyogram in the cat colon: Local effect of sodium ricinoleate. Gastroenterology. 63: 1011-1015. 
30. Stewart, J. J., T. S. Gaginella, W. A. Olsen, and P Bass. 1975. Inhibitory actions of laxatives on motility and water and electrolyte transport in the gastrointestinal tract. J. Pharmacol. Exp. Ther. 192: 458-467.

31. Yau, W. M., and G. M. Makhlouf. 1974. Different effects of hormonal peptides and cyclic adenosine $3^{\prime}, 5^{\prime}-$ monophosphate on colonic transport in vitro. Gastroenterology. 67 : 662-667.

32. Rohde, J. E., and L. C. Chen. 1972. Permeability and selectivity of canine and human jejunum during cholera. Gut. 13: 191-196.
33. Doggenweiler, C. F., and S. Frenk. 1965. Staining properties of lanthanum on cell membranes. Proc. Natl. Acad. Sci. U. S. A. 53: 425-430.

34. LeVeen, H. H., B. Borek, D. R. Axelrod, and A. Johnson. 1967. Cause and treatment of diarrhea following resection of the small intestine. Surg. Gynecol. Obst. 124 : 766-770.

35. Gaginella, T. S., J. J. Stewart, G. W. Gullikson, W. A. Olsen, and P. Bass. 1975. Inhibition of small intestinal mucosal and smooth muscle cell function by ricinoleic acid and other surfactants. Life Sci. 16: 1595-1606. 